\title{
Patriotic self-identification: the case study of Ecological Faculty students at RUDN University
}

\author{
Yulia Zakirova ${ }^{1}$, Anastasia Lazareva $^{2}$, and Nnabueze Kalu Nwankwo $^{3}$ \\ ${ }^{1}$ Peoples Friendship University of Russia (RUDN University), Faculty of Ecology, 6 Miklukho- \\ Maklaya Street, Moscow, 117198, Russian Federation \\ ${ }^{2}$ MGIMO University, 76, Prospect Vernadskogo Moscow, Russia, 119454 \\ ${ }^{3}$ Michael Okpara University of Agriculture, Umudike PMB 7267 Umuahia, Umudike, Abia State, \\ Nigeria
}

\begin{abstract}
The paper aims at providing the initial report of the mental reactions of Ecological Faculty students of RUDN University to the concept of patriotism. The term "patriotism" is used to refer to love of a country as well as to an ideology, which holds that one's primary allegiance should be to one's country and its citizens' needs. Patriotism is considered as a virtue and environmentalism - as one of its important manifestations. The subjects for the present study were 66 Bachelor's students of Ecological Faculty of RUDN University. The survey was conducted in September-October 2020. The participants completed a selfadministered questionnaire. The results were assessed and the conclusions related to the current stage of the study were made.
\end{abstract}

\section{Introduction}

Patriotism is associated with love for one's motherland, pride in it and a strong wish to defend it. It is defined as "love of your country and the desire to defend it" [1]. Patriotic means «showing love for your country and pride in it» [2].

Civic-patriotic education is a priority area of youth policy in Russia, which is reflected in a number of federal decrees and programs such as "Patriotic Education of Citizens of the Russian Federation for 2016-2020" (2015) and the "Strategy for Education Development in the Russian Federation for 2015-2025" (2015) which pay quite a lot of attention to fostering social commitment and initiative in both children and youth. The system of patriotic education in Russia has a public-state character and is implemented in all spheres of education and culture.

However, the patriotic education of young people in the country in general has tended to be military-patriotic, not related to environmental issues. Love for the nature of the country, pride in it, wish to defend it, environmental concerns are not mentioned in the state programs of patriotic education.

Our environment is a part of who we are, so national identity and environmental condition are tied. Love for the motherland begins with love for the nature of the native land, a careful attitude towards it. A patriot, a person with an active civic position cannot stay away from the environmental problems of his native country, region and city. 
Patriotism is a virtue and environmentalism, "concern about the natural environment and how to improve and protect it" [1], is one of its important manifestations.

There is a concept of environmental patriotism - "the belief that a healthy natural environment promotes the strength and safety of the nation. This linkage of environmental laws and patriotism suggests that the priority placed upon environmental protection deserves to be on a par with that of national security" [3].

An eco-patriot is "someone who wants to defend our nation against environmental devastation the same way he/she would want to defend our country against any other threat or invader" [4].

Environmental and patriotic education should be closely tied.

The Faculty of Ecology of RUDN University enrolls candidates for Bachelor's degree and Master's degree educational programs. Graduates become those experts who can deal with the environmental impact assessment and monitoring of the environment, calculation of the risks of the impact of various economic activities on nature, industrial development of the territory, creation of environmental protection schemes, development of systems of waste storage, processing and disposal, eco-economic analysis of the activity of an enterprise [5].

Therefore, the great need exists for ecologists to be socially committed and socially responsible, i.e. work in ways that are not harmful to the society or the environment. They ought to carefully consider the ethical aspects and the overall consequences of their work, to be aware of the effect that technology, industry, economic expansion have on the environment of the country, to have a vested interest in protecting our environment, in ensuring that this unique country is for generations to come [6]. The paper aims at providing the initial report of the mental reactions of Ecological Faculty students to the concept of patriotism.

\section{Methodology}

The subjects for the present study are 66 Bachelor's students of Ecological Faculty of RUDN University born during the period of 1998-2003. The survey was conducted in September-October 2020. The participants completed a self-administered questionnaire. The results were assessed and the conclusions related to the current stage of the study were made.

All the participants were asked the questions related to patriotic self-identification, pride in the country's achievements, pride in the nature of the native country and environmental protection as part of patriotism.

The students were provided with a statement assuring them there was no right or wrong answer, requesting honest answers, promising confidentiality, and expressing appreciation.

\section{Results}

\subsection{Patriotic self-identification}

The participants were asked a question: "Do you consider yourself a patriot?" $33 \%$ - yes, $49 \%$ - to a certain extent, $6 \%$ - difficult to answer, $12 \%$ - no (Fig. 1). 


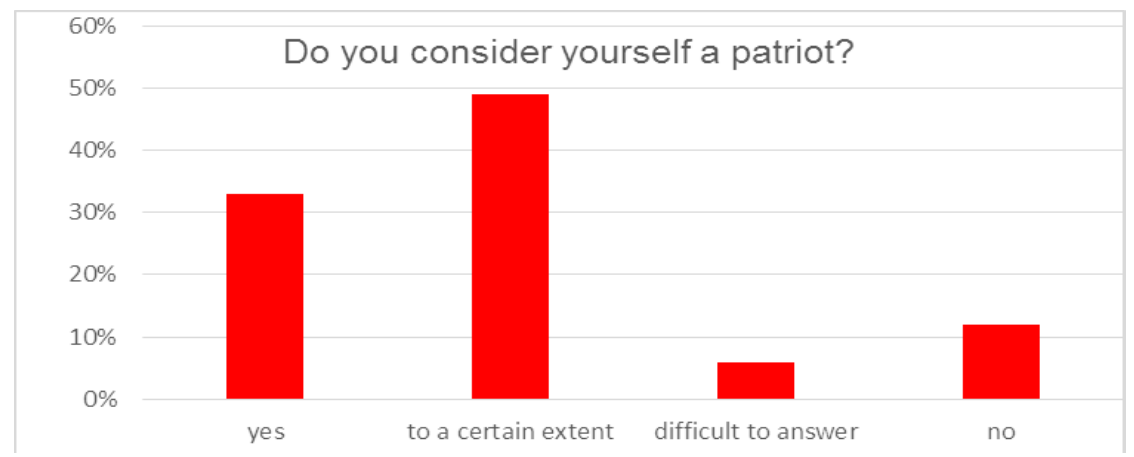

Fig. 1. Patriotic self-identification.

Most of the participants tend to be moderately patriotic. Only $12 \%$ of participants do not regard themselves as patriots at all.

\subsection{Pride in the country's achievements}

The participants were asked a question: “Are you proud of your country's achievements?" $47 \%$ - yes, $38 \%$ - difficult to answer, $15 \%$ - no (Fig. 2).

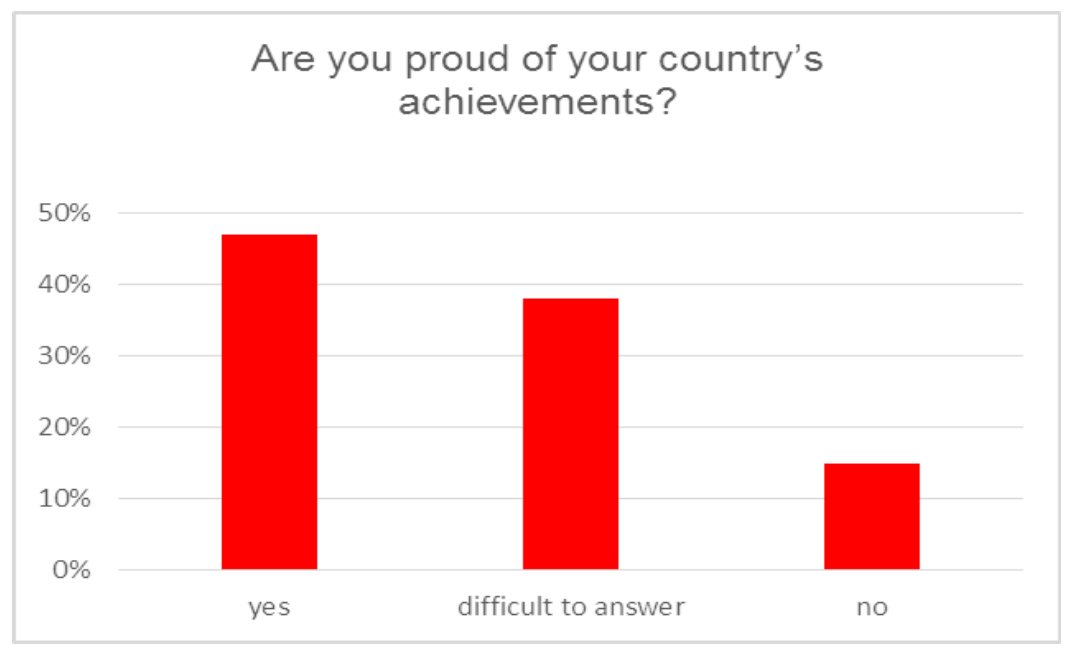

Fig. 2. Pride in the country's achievements.

$47 \%$ of students have a sense of pride in the country's achievements. Less than $15 \%$ of the participants do not consider the country's achievements as a source of pride.

\subsection{Pride in the nature of the native country}

The participants were asked a question: "Are you proud of the nature of your country?"

$91 \%$ - yes, difficult to answer - 8\%, 1\% - no (Fig. 3). 


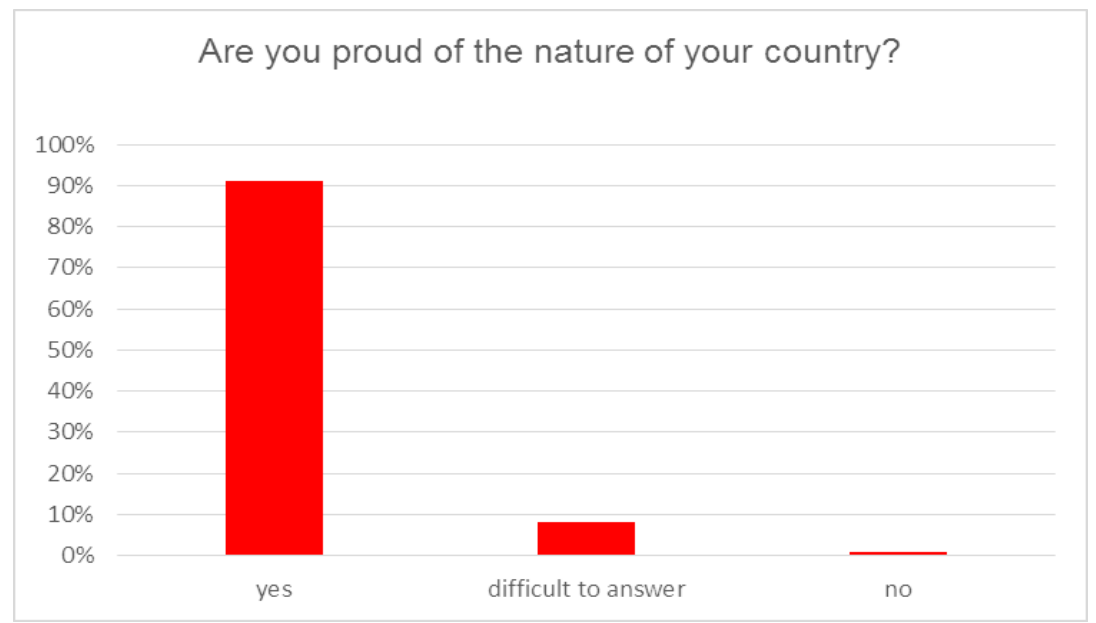

Fig. 3. Pride in the nature of the native country.

Nearly all participants, the students of the Ecological Faculty, take great pride in the nature of their motherland. Only $8 \%$ of the respondents had a feeling of doubt and uncertainty when dealing with the question.

\subsection{Environmental patriotism}

The participants were asked a question: "Do you consider environmental protection as part of patriotism?"

$76 \%$ - yes, $12 \%$ - difficult to answer, $12 \%$ - no (Fig. 4 ).

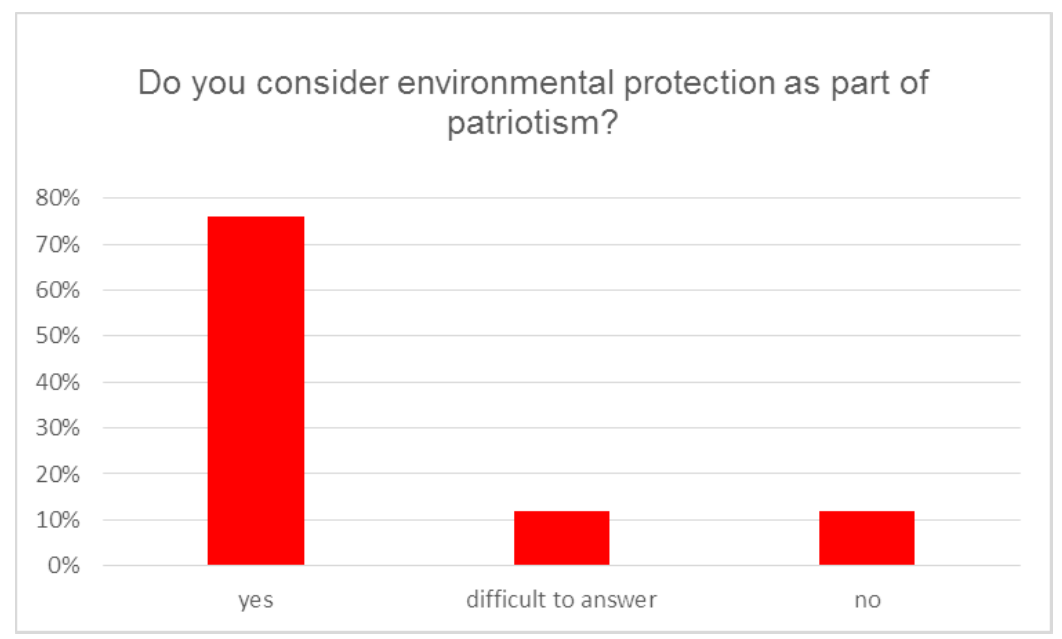

Fig. 4. Environmental protection as part of patriotism.

More than $70 \%$ of students associate environmental protection with patriotism.

\section{Conclusions}

It is crucial that future ecologists should be socially committed and socially responsible, i.e. work in ways that are not harmful to the society or the environment. They ought to carefully consider the ethical aspects and the overall consequences of their work, to be 
aware of the effect that technology, industry, economic expansion have on the environment of the country, to have a vested interest in protecting our environment, in ensuring that this unique country is for generations to come. Environmental and patriotic education should be closely tied. However, the patriotic education of young people in the country in general has tended to be military-patriotic, not related to environmental issues. Love for nature of the country, pride in it, wish to defend it, environmental concerns are not mentioned in the state programs of patriotic education.

The paper aimed at providing the initial report of the mental reactions of Ecological Faculty students of RUDN University to the concept of patriotism.

The analysis has shown that the respondents tend to be moderately patriotic. Less than $15 \%$ of the participants do not consider the country's achievements as a source of pride. Most participants, students of the Ecological Faculty, take great pride in the nature of their motherland $(91 \%)$. More than $70 \%$ of students associate environmental protection with patriotism.

Eco-patriotic education could be a promising peaceful alternative to military-patriotic education. Regarding ecology students, it could contribute to the desire to preserve the natural and cultural heritage, to ensure the necessary balance between anthropogenic impact on the environment and its protection, provide a sound basis for the implementation of sustainable development programs in their professional career.

\section{References}

1. A.S. Hornby, Oxford Advanced Learner's Dictionary of Current English (Oxford University Press Oxford, Retrieved from https://www.oxfordlearnersdictionaries.com/definition/english/basis?q=basis )

2. Cambridge international dictionary of English, Cambridge: Cambridge University Press. Retrieved from https://dictionary.cambridge.org/ru/

3. Ch.A. Klein, Environmental Patriotism. Beyond environmental law: policy proposals for a better environmental future (Cambridge University Press, 2009 ).

4. K. Butler, Journalist Jennifer Grayson defines the eco-patriot (2011). Retrieved from https://www.scpr.org/blogs/environment/2011/08/03/3214/journalist-jennifer-graysondefines-eco-patriot/

5. http://eng.rudn.ru/education/educationalprograms/?institute $=273 \&$ level_of_training $=487$

6. Y. Nigmatzyanova, N. Valeeva, A. Guslyakova, N. Merkushina, New Trends and Issues Proceedings on Humanities and Social Sciences, 5(5), 40-48 (2018) 